\title{
Conditions for acquisition of nationality by operation of law or by lodging a declaration of option
}

Citation for published version (APA):

de Groot, G. R. (2002). Conditions for acquisition of nationality by operation of law or by lodging a declaration of option. Maastricht Journal of European and Comparative Law, 121-160.

https://doi.org/10.1177/1023263X0200900202

Document status and date:

Published: 01/01/2002

DOI:

10.1177/1023263X0200900202

Document Version:

Publisher's PDF, also known as Version of record

\section{Please check the document version of this publication:}

- A submitted manuscript is the version of the article upon submission and before peer-review. There can be important differences between the submitted version and the official published version of record.

People interested in the research are advised to contact the author for the final version of the publication, or visit the DOI to the publisher's website.

- The final author version and the galley proof are versions of the publication after peer review.

- The final published version features the final layout of the paper including the volume, issue and page numbers.

Link to publication

\footnotetext{
General rights rights.

- You may freely distribute the URL identifying the publication in the public portal. please follow below link for the End User Agreement:

www.umlib.nl/taverne-license

Take down policy

If you believe that this document breaches copyright please contact us at:

repository@maastrichtuniversity.nl

providing details and we will investigate your claim.
}

Copyright and moral rights for the publications made accessible in the public portal are retained by the authors and/or other copyright owners and it is a condition of accessing publications that users recognise and abide by the legal requirements associated with these

- Users may download and print one copy of any publication from the public portal for the purpose of private study or research.

- You may not further distribute the material or use it for any profit-making activity or commercial gain

If the publication is distributed under the terms of Article $25 \mathrm{fa}$ of the Dutch Copyright Act, indicated by the "Taverne" license above, 
G.R. de Groot ${ }^{*}$

\section{Conditions for Acquisition of Nationality by Operation of Law or by Lodging a Declaration of Option ${ }^{1}$}

\section{$\S 1$. Introductory Remarks}

The object of this contribution is to provide an inventory of the rules regarding the acquisition of the nationality of a state. Nationality should indicate a genuine link between a state and a person. ${ }^{2}$ Therefore the nationality law of a state gives rules which determine the conditions under which that state's nationality is attributed to a person who is deemed to have a genuine link to it. Furthermore, rules are given that set out the conditions that must be fulfilled to acquire a state's nationality on the basis that the person involved has built up a link with the state. Finally, rules are given on the loss of nationality.

In $\S 2$ a comparative description of the grounds for the acquisition of a nationality by operation of the law will be given. $\S 3$ will describe which categories of persons are entitled to acquire a nationality by lodging a declaration of option. In this paper, prepared for the Second Conference on Nationality initiated by the Council of Europe, no attention will be given to the possibility of acquisition of nationality by

* Professor of Comparative Law and Private International Law at the University of Maastricht.

1. This paper is a slightly updated version of a paper presented by the author by invitation of the Council of Europe during the 2nd European Conference on Nationality (Strasbourg, 8-9 October 2001) on 'Challenges to National and International Law on Nationality at the Beginning of the New Millennium'. A French version of the paper was distributed under the title 'Conditions d'acquisition de la nationalité ex lege ou par déclaration d'option'. The conclusions of the 2nd European Conference on Nationality are added to this publication in Annex 1.

2. Compare the Nottebohm decision ICJ Reports 1955, 4 (23); Fontes iuris gentium, Series A, sectio 1, tomus 5,81 . 
naturalization. ${ }^{3}$ Nor, in principle, will the grounds for the loss of nationality be addressed in this contribution. ${ }^{4}$

It is useful to describe the rules on the acquisition of a nationality by operation of law, and the cases where a nationality can be acquired by declaration of option, for several reasons. First of all, it provides a foundation for the elaboration of ideas on desirable grounds for attribution of nationality and on regulations which give some categories of foreigners the possibility to acquire the nationality in a way other than by naturalization because it is very likely that they have (built up) a significant link with the state involved.

To develop such ideas is appropriate in view of art. 15 (1) of the Universal Declaration of Human Rights ${ }^{5}$ which lays down that everybody is entitled to a nationality, however it does not indicate the conditions which entitle a person to a certain nationality. It is therefore attractive to study the similarities and differences between the various rules on acquisition of nationality in order to develop recommendations on rules for acquisition of nationality. It has to be stressed that up to now only a few international documents exist with a couple of concrete rules on acquisition of nationality. The most elaborate provision can be found in art. 6 of the European Convention on Nationality (Strasbourg 6 November 1997 - hereinafter the ECN), ${ }^{6}$ but even the rules of that provision have - in part - a quite general character. ${ }^{7}$ Due to the modest number of provisions dealing with the acquisition of nationality in international instruments and the fact that these rules are not very detailed, the rules on the acquisition of nationality in the various States differ remarkably.

Furthermore, knowledge of the rules on acquisition of nationality is essential to be able to compare and discuss rules on naturalization in a comparative perspective, particularly statistics on naturalization. It is obvious that rules on naturalization are superfluous for

3. Another paper prepared for the 2nd European Conference on Nationality by Andrew Walmsley ("The acquisition of nationality through naturalization; An assessment of European legislation') is completely devoted to that way of acquiring nationality, describing the conditions which have to be fulfilled in order to qualify for naturalization. In Walmsley's contribution attention is paid also to categories of persons who enjoy a privileged position in the case of application for naturalization because some of the normal conditions do not apply to them.

4. See for a comparative inventory in comparison with the provisions of Art. 7 and 8 European convention on nationality my report 'Loss of nationality' for the German Marshall Fund Project on Dual Nationality (1999/2000), which will be published in David A. Martin and Kay Hailbronner, Rights and Duties of Dual Nationals: Evolution and Prospects, (Kluwer Law Intemational, 2002), chapter 2.

5. Adopted on 10 December 1948. Resolution 217A (III) of the General Assembly of the United nations, UN General Assembly Official Records 3rd Session, Resolutions part I, 71. See on this resolution MaricHélène Marescaux, 'Nationalité et statut personnel dans les instruments des Nations Unies', in Michel Verwilghen, Nationalité et statut personnel, (Bruylant, 1984), 18-24.

6. European Treaties Series No. 166 .

7. See Gerard-René de Groot, 'The European convention on nationality, a step towards a ius commune in the field of nationality law', 7 Maasiricht Joumal of European and Comparative Law 2 (2000), 117. 
those categories of persons who already acquire the nationality of a country ex lege or can acquire this nationality by declaration of option.

A justification for the choice of jurisdictions included in this study is necessary. Considering that this paper was intended for the second conference on nationality law of the Council of Europe, an attempt is made to include a considerable number of the jurisdictions of the Council's member states. Because of the availability of materials in languages which could be read by the author the research was restricted to the Member States of the European Union and the European Economic Area. Furthermore information is included on the nationality legislation of Hungary, Moldova and Slovakia, because these States already ratified (as did Austria, the Netherlands, Portugal and Sweden) the ECN. Finally, some data in respect to the nationality legislation of some candidate member states of the European Union were added. Of course the information will focus on the main issues. Many details had to be omitted, due to the permitted maximum size of this paper.

In this article, references to the different jurisdictions' legislation are made by using abbreviations. For example, ' 15 (1) (b) NET' refers to 'art. 15 paragraph 1 , lit. b of the Nationality $\mathrm{Act}^{8}$ of the Netherlands'. In order to indicate the nationality legislation of the different countries the following abbreviations are used: ${ }^{9}$ AUS $=$ Austria; BEL $=$ Belgium; $\mathrm{CZE}=$ Czech Republic; DEN = Denmark; EST = Estonia; FIN = Finland; FRA $=$ France $;$ GER $=$ Germany $;$ GRE $=$ Greece $;$ HUN $=$ Hungary; $I C E=$ Iceland $;$ IRE $=$ Ireland; ITA = Italy; LUX = Luxembourg; $\mathrm{MOL}=$ Moldova; NET = Netherlands; NOR $=$ Norway $; \mathrm{POR}=$ Portugal $; \mathrm{POL}=$ Poland $\mathrm{SLK}=$ Slovakia; $\mathrm{SLN}=$ Slovenia; SPA $=$ Spain; SWE $=$ Sweden; SWI $=$ Switzerland; UK = United Kingdom .

Of course, in principle, references are made to the legislation in force in the various countries. An exception is made for the Netherlands where, if the contrary is not indicated, references to the nationality statute include the modifications which will come in force in 2003. ${ }^{10}$ In respect of Polish nationality law, references are made to the bill on Polish nationality (o obywatelstwie polskim) which was pending in parliament in $1999 / 2000 .{ }^{\text {Il }}$ A list of relevant nationality statutes of the States included in this report is given in Annex 2.

Of course, I realize that it is likely that some references are not completely up-to-date due to the rapid legislative developments in the field of nationality law in the various countries. Furthermore, because of the complexity of many details of nationality

8. This abbreviation is also used for countries where the nationality provisions are included in the civil code, such as France and Spain.

9. These abbreviations correspond with those used in the European Bulletin on Nationality (English edition).

10. Rijkswet (Kingdom Statute) of 21 December 2000, Staatsblad 618.

11. This bill was finally not accepted by the Senate. A new draft is under preparation. 
statutes, my interpretation of some regulations may not be completely correct. ${ }^{12}$ But for the moment I hope this survey will provide a solid basis for fruitful discussions on the desirable developments of the nationality laws of the Member States of the Council of Europe.

\section{§ 2. Acquisition Ex Lege}

\section{A. CHILDREN OF A NATIONAL (ACQUISITION IURE SANGUINIS/BY DESCENT)}

\section{A Matre 13 $^{13}$}

Almost all states provide for, in principle, the acquisition of their nationality if the mother of a child possesses the nationality involved at the moment of the child's birth. ${ }^{14}$ Only in the case of a birth abroad do some states make an exception to this rule (see below). The old practice of the predominance of the acquisition iure sanguinis a patre has been abolished in nearly all the states included in this contribution. In Switzerland, 57a SWI provides however, that a child of a Swiss mother who acquired her nationality by a previous marriage only acquires Swiss nationality if he does not acquire another nationality or becomes stateless before attaining the age of majority. ${ }^{15}$

In principle, the mother of a child is the woman who gave birth to the child (for example, as stated in 1 (1) (c) NET; 50 (9) UK). This is in conformity with the ruling of the European Court of Human Rights in re Paula Marckx $v$. Belgium ${ }^{16}$ and furthermore with the Convention on the establishment of the maternal affiliation of children born out of wedlock. ${ }^{17}$ Therefore, in principle, a woman does not need to recognize a child born out of wedlock in order to establish a family relationship between herself and the child. However, some civil codes still contain provisions on the recognition by the mother of children born out of wedlock, along with provisions which allow the judicial establishment of maternity. In very special cases, for example children born as a consequence of an incestuous relationship, some codes provide that the establishment of

12. I would be grateful to receive additional information if my references or descriptions were incomplete or incorrect. These comments will enable me to improve this paper.

13. See Gerard-René de Groot, Staatsangehörigkeitsrecht im Wandel, (Heymanss Verlag, 1989), 190-194, $199,200$.

14. 7 (1) and (3) AUS; 8 (1) BEL; 3 (a) CZE; 1(1) DEN; 5 (1) (1) EST; 1 (1) FIN; 18 FRA; 4 (1) GER; 1 (1) GRE; 3 (1) HUN; 1 (1) (1 and 2) ICE; 6 (2) IRE; 1 (1) (a) ITA; 1 (1) LUX; 11 (1) (a) MOL; 3 (1) NET; 1 (a) NOR; 11 (1) POL; 5 (1) (a) SLK; 4 (1) and (2) SLN; 17 (1) (a) SPA; 1 (1) SWE; 1 (1) (a) and (b) SWI; 1 and 2 UK.

15. This provision has a transitory character because since 1992 the foreign wife of a Swiss man does not acquire Swiss nationality by her marriage anymore. The restriation on the transmission of nationality was since then moved from Art. 2 to Art. 57a SWI.

16. Marckx $\vee$ Belgium, ECHR 13 June 1979, ECHR Series A, Vo. 31.

17. Convention relative à l'établissement de la filiation maternelle des enfants naturels, Brussels 12 September 1962, Tractatenblad 1963,93 . 
a family relationship between a child and the mother may be forbidden. Nevertheless, even in such cases the nationality position of the offspring has to be regulated.

The acquisition of a nationality iure sanguinis (a matre et a patre) is prescribed by art. 6 ECN. According to paragraph 1, each State Party shall provide in its internal law for its nationality to be acquired ex lege by a child, one of whose parents possesses at the time of the child's birth the nationality of that State Party. States are allowed to make an exception for children bom abroad. However, the explanatory report (No. 65) ${ }^{18}$ to this provision underscores that any provisions limiting the transmission of the nationality of a parent to a child born abroad should not apply if such a child would become stateless. The report continues:

It must be added that the acquisition of the nationality of one of the parents at birth on the basis of the ius sanguinis principle, by children born abroad should be automatic and not made conditional upon a registration or option, the absence of which would make them stateless.

Recommendation R 99 (18) of the Committee of Ministers of the Council of Europe on the avoidance and the reduction of statelessness adopted on 15 September 1999 underscores this desideratum in rule II A, sub a: 'Exceptions made with regard to children born abroad should not lead to situations of statelessness.'

This is an important addition to the Convention, which ideally should be added to the actual text of the Convention, preferably in an additional protocol.

\section{Cases of non-acquisition iure sanguinis by children born abroad}

Several of the countries studied in this contribution make use of the possibility to provide for a limitation of their nationality in the case of birth abroad.

According to 8 (1) (2) BEL, Belgian nationality is acquired by every child of a Belgian parent bom in Belgium, but by a child of a Belgian parent who was born abroad only if one of three different conditions is fulfilled: a) the parent was born in Belgium or in territories under Belgian administration ('dans des territoires soumis à la souveraineté belge ou confiés à l'administration de la Belgique'), ${ }^{19}$ b) the Belgian parent registers the child as a Belgian national within five years after the child's birth; c) the child is otherwise born stateless or loses his (other) nationality before his eighteenth birthday ('ou ne conserve pas jusqu'à l'age de dix-huit ans ou son émancipation avant cet âge, une autre nationalité').

18. See the website of the Council of Europe (http://www.coe.int) under Treaty ETS no. 166.

19. Congo, Rwanda and Burundi. 
Since 1 January 2000 the German Nationality Act provides in 4 (4) GER, that German nationality will no longer be acquired by descent if a child of German parent(s) is born abroad and the parent was also born abroad after 31 December 1999 and the parent has his habitual residence outside of Germany ('wenn der deutsche Elternteil nach dem 31. Dezember 1999 im Ausland geboren wurde und dort seinen gewöhnlichen Aufenthalt $\left.h a t^{\prime}\right)$. German nationality is nevertheless acquired if the child would otherwise be stateless. If the child does not acquire German nationality of the parent(s) ex lege because of the 'double' birth abroad, a parent can register the child as a German national within one year after the child's birth. ${ }^{20}$

British nationality law also contains a limitation of the transmission by descent in the case of birth abroad. The relevant British provisions are quite complicated. Section 2 UK states, inter alia, that a person born outside the United Kingdom shall be a British citizen if at the time of the birth his father or mother (a) is a British citizen otherwise than by descent (e.g. British because of birth in the UK or British by naturalization); ${ }^{21}$ or (b) is a British citizen and is outside the United Kingdom in British service, his or her recruitment for that service having taken place in the United Kingdom; or (c) is a British citizen and is outside the United Kingdom in service under a Community institution, his or her recruitment for that service having taken place in a country which at the time of the recruitment was a member of the European Community.

Section 3 UK deals with the nationality status of, to put it briefly, the second generation born abroad. According to 3 (2) UK, a person born outside the United Kingdom shall be entitled, on an application for his registration as a British citizen made within a period of twelve months from the date of the birth, to be registered as such a citizen if the requirements specified in 3 (3) UK or, in the case of a person born stateless, the requirements specified in paragraphs (a) and (b) of that subsection, are fulfilled in the case of either that person's father or his mother ('the parent in question'). These requirements are:

a) that the parent in question was a British citizen by descent at the time of the birth; and

b) that the father or mother of the parent in question

(i) was a British citizen otherwise than by descent at the time of the birth of the parent in question; or

20. This limitation on the transmission of German nationality is completely new in German nationality law, and it will take a considerable amount of time before this modification will have concrete results. The first children who will not acquire German nationality because of this limitation are the children of the German children born outside of Germany in the year 2000.

21. Children of naturalized British citizens therefore always acquire British nationality in case of birth abroad. The High Court, Queens Bench Division decided on 6 October 2000 per Mr. Justice Gibbs, that British citizens by descent are entitled to seek naturalization (Law report 17 October 2000). 
(ii) became a British citizen otherwise than by descent at commencement of the British Nationality Act on 1 January 1983, or would have become such a citizen otherwise than by descent at commencement but for his or her death; and

c) that, as regards some period of three years ending with a date not later than the date of the birth

(i) the parent in question was in the United Kingdom at the beginning of that period; and

(ii) the number of days on which the parent in question was absent from the United Kingdom in that period does not exceed 270.

Section 3 (4) UK opens up a possibility for the Secretary of State to allow a later registration than within the twelve months immediately after the child's birth by providing that 'if in the special circumstances of any particular case the Secretary of State thinks fit, he may treat subsection (2) as if the reference to twelve months were a reference to six years'.

If a person is born abroad as a child of a British parent without acquiring British citizenship, he may nevertheless acquire a right to registration if the conditions of 3 (5) UK are fulfilled:

(5) A person born outside the United Kingdom shall be entitled, on an application for his registration as a British citizen made while he is a minor, to be registered as such a citizen if the following requirements are satisfied, namely

(a) that at the time of that person's birth his father or mother was a British citizen by descent; and

(b) subject to subsection (6), that that person and his father and mother were in the United Kingdom at the beginning of the period of three years ending with the date of the application and that, in the case of each of them, the number of days on which the person in question was absent from the United Kingdom in that period does not exceed 270 ; and

(c) subject to subsection (6), that the consent of his father and mother to the registration has been signified in the prescribed manner.

According to Irish nationality law, Irish nationality is not acquired ex lege in case of birth outside of Ireland if the father or mother through whom the child can derive Irish nationality was also born outside of Ireland, unless the relevant parent was at the time of the child's birth in Irish public service. The child acquires Irish nationality by registration as a Irish citizen (7 (3) juncto $27 \mathrm{IRE}$ ) on application of the parent or of the person himself. 
Another country with a limitation on the transmission of nationality iure sanguinis in case of birth abroad is Portugal. 1 (1) (b) POR provides that the children of a Portuguese father or a Portuguese mother born abroad acquire Portuguese nationality by birth if they declare that they want to be Portuguese, or if they register the birth in a Portuguese civil register. If the parents reside abroad in the service of Portugal, their children acquire Portuguese nationality ex lege (1 (1) (a) POR).

According to Slovenian nationality law, a child born abroad acquires Slovenian nationality, if both parents possess Slovenian nationality (4 (1) SLN). If only one parent is Slovenian this nationality is in principle only transmitted if the child is born in Slovenia (4 (2) SLN. In the case of birth abroad of one Slovenian parent, the child acquires Slovenian nationality by registration as such before the age of 18 or by settling in Slovenia together with the Slovenian parent. If the child has already reached the age of 14 his consent is required ( 8 SLN). If the child would be stateless if he does not acquire Slovenian nationality registration is not necessary: in that case, the nationality is acquired ex lege ( 5 SLN). Between the age of 18 and 23 a child of one Slovenian parent who did not acquire Slovenian nationality can acquire this nationality by lodging a declaration of option ( $6 \mathrm{SLN})$.

It is obvious, that it is desirable for Ireland, Portugal and the United Kingdom to provide for an acquisition ex lege if the child born abroad would otherwise be stateless.

The reason to limit the transmission of nationality in case of birth abroad is linked to the function of the institution of nationality as such. As was already mentioned above, nationality should be a manifestation of a genuine link between a person and a state. If several generations have already been born abroad, it becomes less likely that the next generations will develop a link which justifies the possession of the nationality of the State of their ancestors' origin. In that respect, limiting on the transmission of nationality in the case of birth outside the country is - in principle - acceptable. This is also the opinion stated in the explanatory report on Art. $6 \mathrm{ECN}$ (No. 65 and 66):

However, it should be noted that this provision does not require a State to grant its nationality to children born abroad generation after generation without limitation, when such children have no links with that State. Normally, such children will acquire the nationality of the State of birth (with which - presumably - they have a genuine and effective link).

An alternative to limiting the transmission of a nationality at birth is for the legislator to provide for the loss of nationality if a national habitually resides abroad and no longer has a sufficient genuine link with the state involved. This ground for loss is allowed by Art. 7 (e) ECN. Such a ground for loss exists in the nationality legislation of inter alia Belgium (22 (1) (5) BEL), Denmark (8 (1) DEN), Finland (8b FIN), France (23-6 FRA), Iceland (8 ICE), Luxembourg (25 (8) LUX), the Netherlands (15 (1) (c) NET, Norway (8 NOR), 
Sweden (14 SWE) and Switzerland (10 SWI). ${ }^{22}$ It is remarkable that Belgium limits the transmission of nationality in case of birth abroad, but uses also this ground for loss.

It is obvious that a provision on loss of nationality due to the lack of a sufficient link is to be preferred to limiting the transmission of nationality in case of bitth abroad if a state wants to give to the child the possibility to decide for himself whether to develop a link with the state of his ancestors in order to retain his inherited nationality. In that case, it is desirable to grant the child a reasonable period after having attained the age of majority to establish significant ties with the state of his inherited nationality in order to keep this nationality. On the other hand, one has to realize, that almost the same result can be reached by granting an option right to children who did not acquire the nationality of their parent because of their birth abroad.

If the acquisition of nationality by a child born abroad depends on an action to be undertaken by a parent (e.g. registration) or on developing significant ties whilst the child is still a minor (e.g. a period of residence in the country of the inherited nationality before the age of majority) without compensating this with an option right to (re)acquire the nationality after having attained the age of majority, parent(s) are given considerable power to determine the nationality position of the child. One can question, whether that is desirable. Compare in this context the principle mentioned in art. 8 (1) of the Convention on the Rights of the Child, ${ }^{23}$ which provides that

states should undertake to respect the right of a child to preserve his or her identity, including nationality, ... as recognized by law without unlawful interference.

Of course, this is a very weak statement and the rules described above can certainly not be qualified as unlawful interference, but the principle opens our eyes to the fact that a child's nationality is a part of his identity and that it should not be lost whilst the child is a minor without good reasons. Furthermore, one has to realize that the choices which states make in this respect should also have consequences for the provisions which extend the loss of nationality by parents to their children ${ }^{24}$ (see below $\S 2.1$ ) and the grounds for loss of nationality by minors in general. ${ }^{25}$ Special attention should be given to the possibilities which parents possess to represent their children in nationality matters.

22. See Gerard-René de Groot, Staatsangehörigkeitsrecht im Wandel, 290-295; furthermore De Groot, 'Loss of nationality', Par. 5.

23. Concluded in New York 20 November 1989.

24. See Gerard-René de Groot, "Loss of nationality", Par. 8.

25. See Gerard-René de Groot, 'Loss of nationality", Par. 6 and 12. 


\section{A Patre ${ }^{26}$}

a. Children born within Wedlock

All states provide, in principle, for the acquisition of their nationality if the father of a child possesses the nationality involved at the time of the child's birth. Of course, it has to be mentioned again that Belgium, Germany, Ireland, Portugal and the United Kingdom provide for an exception to this rule if the child is born abroad.

In order to conclude that a child derives a certain nationality iure sanguinis a patre, it has to be determined that a person is the child of a certain 'father' in the sense of the provisions involved.

All states provide that a child born within wedlock acquires the nationality of the husband of the mother. ${ }^{27}$ Furthermore, the nationality can be derived from this father even if he died before the child's birth. ${ }^{28}$

The situation is different if the parents are not married to each other. Article 6 ECN expressly allows an exception in respect of the acquisition iure sanguinis regarding children born out of wedlock. If the family relationship between a child born out of wedlock and his father is established by recognition, legitimation or a judicial decision, this does not necessarily have as a legal consequence the acquisition of the father's nationality. A state may provide that the child has to fulfill additional requirements before he acquires or can acquire the nationality of his father.

Nevertheless, many countries provide that children born out of wedlock also acquire the nationality of their father if a family relationship exists between him and the child. This is explicitly laid down in, for example 4 (1) GER and implicitly in 8 BEL; 18 FRA; and 2 I 7 (1) IRE. Almost all countries require that the family relationship in that case must be determined before the child reaches the age of majority; as provided by for example 20-1 FRA. Paragraph 4 (1) GER is an exception to this, it must be determined before the age of 23 .

In some countries not all children born out of wedlock acquire the father's nationality. This is the case in for example Austria, Denmark, Finland, Iceland, the Netherlands, Norway, Sweden, Switzerland and the United Kingdom.

26. See Gerard-René de Groot, Staatsangehörigkeitsrecht im Wandel, 194-196, 201-203.

27. Explicitly provided in 7 (1) (a) AUS; 1 (1) DEN; 1 (2) FIN; 1 (1) ICE; 1 (b) NOR; 1 (3) SWE; 1 (1) (a) SWI and implicitly because of general clause in 8 (1) BEL; 3 (a) CZE; 5 (1) (1) EST; 18 FRA; 4 (1) GER; 1 (1) GRE; 3 (1) HUN; 7 (1) IRE; 1 (1) (a) ITA; 1 (1) LUX; 11 (1) (a) MOL; 3 (1) NET; 11 (1) POL; 1 POR; 5 (1) (a) SLK; 4 SLN; 17 (1) (a) SPA.

28. Expressly stated in 7 (1) (b) AUS; 8 (2) BEL; 5 (1) (2) EST; 1 (3) FIN; 9 IRE; 3 (1) NET; 1 (c) NOR; 1(4) and (5) SWE. Compare also 1 (1) LUX. 


\section{b. Children born out of Wedlock, but legitimated by a Subsequent Marriage of the Parents}

In most countries a child born out of wedlock, but legitimated by a subsequent marriage between the mother and the father acquires ex lege the nationality of the father by legitimation. Almost all countries require that the legitimation takes place whilst the child is still a minor (20-1 FRA). In some countries legitimation is mentioned as a separate ground for acquisition. ${ }^{29}$ In other countries, this ground for acquisition is covered by the general provision that children acquire the nationality of a parent if the family relationship with this parent is established whilst the child is still a minor. ${ }^{30}$

In Austria, an additional rule is of importance: legitimation is a ground for acquisition of nationality, but if the minor is already over 14 years of age, his consent and the consent of his legal representative to the acquisition of nationality is required (7a (2) AUS). Under certain conditions a required consent can be replaced by a decision of the court in the interest of the minor involved (7a (5) AUS).

According to Netherlands nationality law, legitimation does not have ex lege nationality consequences. Legitimation no longer exists as a legal institution in the family law of the Netherlands because it was considered to be superfluous after the implementation of the principle of equal treatment of children born within and out of wedlock. ${ }^{31} \mathrm{~A}$ legitimation which took place under foreign law will under certain circumstances be recognized in the Netherlands, but will not have ex lege nationality consequences. Under certain conditions the legitimated child has an option right to Netherlands nationality $\left(6(1)(c)\right.$ NET) ${ }^{32}$

\section{c. Children born out of Wedlock, but recognized by the Father}

Several countries provide that recognition of a child born out of wedlock by a man has as a consequence the acquisition of the man's nationality. Again, most countries require that the recognition takes place during the child's minority (compare 14 POR). In Germany, the recognition must have taken place before the child reaches the age of 23 years. In some countries, recognition is mentioned as a separate ground for acquisition of nationality. ${ }^{33}$ In some other countries, this ground for acquisition is covered by a general provision (see above the provisions mentioned in $\S 2 . A .2 . b$ ).

29. See: 2 DEN; 3 FIN; 3 (2) HUN; 2 NOR; 4 SWE; 1 (2) (a) SWI.

30. See 8 BEL; 5 (1) (1) EST; 18, juncto 20 and 20-1 FRA; 2 ITA; 1 (1) LUX; 11 (1) (a) MOL; 1 POR; 17 (1) (a) SPA; compare also 6 (2) IRE juncto Sect. 5 Status of Children Act 1987.

31. Compare Iceland where the provision on legitimation was abolished in 1998.

32. This provision will come in force in 2001. At the moment 4 NET still provides for ex lege nationality consequences, if the legitimation took place during the minority of the child. See below Part III, 5a.

33. See 4 (1) GER; 2 GRE; 3 (2) HUN; 2 (1) ITA. See also 2a NOR. 
1 (DEN) and 1 (2) SWE provide that a child born out of wedlock obtains exclusively ex lege the nationality of the father if he is born in Denmark or Sweden respectively. A child of a Swedish father born out of wedlock outside of Sweden acquires Swedish nationality if the father registers the child as a Swedish citizen (5 SWE) ${ }^{34}$

2 ICE provides that a child born abroad of an unmarried woman and an Icelandic man acquires Icelandic nationality on application of the father before the child reaches the age of 18 years. The father has to consult the child if he is over 12 years old. If the father submits, in the opinion of the Icelandic authorities, satisfactory evidence concerning the child and his paternity, the child acquires Icelandic nationality on confirmation from the ministry. ${ }^{35}$

In the Netherlands, recognition does not have ex lege nationality consequences. Under certain conditions the recognized child can opt for Netherlands nationality (6 (1) (c) NET) ${ }^{36}$ However, if the father recognizes the child before its birth, the child acquires Netherlands nationality ex lege because that case is covered by the general provision of 3 (1) NET.

\section{d. Children born out of Wedlock of a Man, whose Fathership was Judicially established}

In some countries the judicial establishment of paternity is expressly mentioned as a ground for the acquisition of nationality. So e.g. 4 CZE; 4 (1) GER; 3 (2) HUN; 4 NET; 2a NOR. In a considerable number of other countries, this ground for acquisition is covered by a general provision (see above). Again, most countries provide that the judicial establishment has to take place during the minority of the child in order to have nationality consequences ex lege. In Germany, the procedure regarding the judicial establishment of paternity must have been started before the $23 \mathrm{rd}$ birthday of the child.

For the Netherlands, it has to be mentioned that a judicial establishment of paternity is not yet regulated in the Nationality Act as a ground for acquisition of nationality, but a statute introducing this ground for acquisition will come into force in 2003. The possibility of a judicial establishment of paternity was only very recently introduced into Netherlands family law (since 1 April 1998) and the Nationality Act has not been adapted yet to this new legal institution.

34. It has to be mentioned that the provisions involved are already considerably more generous than the prior Par. 1 and 2a SWE.

35. Compare 2a NOR.

36. This provision will come in force in 2001. At the moment 4 NET still provides for ex lege nationality consequences, if the recognition took place during the minority of the child. See below $\S 3$.E.1. 
However, courts in the Netherlands have already come to the conclusion that at the moment judicial establishment of paternity has also nationality consequences because it is covered by the general provision that a child acquires Netherlands nationality a patre, if at the time of its birth the father possesses this nationality (3 (1) NET). Because Art. 207 (5) of the Civil code of the Netherlands provides that a judicial establishment of patemity has retroactivity to the moment of birth, the conditions of 3 (1) NET after the judicial establishment of the paternity have been fulfilled. ${ }^{37}$

\section{Some elements for an evaluation}

Some critical remarks on the use of the exception allowed by Art. 6 ECN, in respect of the transmission of the nationality iure sanguinis a patre in case of children born out of wedlock, are appropriate. If I see it correctly, three different arguments are used in order to exclude (some) children born out of wedlock from the transmission of the nationality of their father:

a) One could argue, that a child born out of wedlock will less likely develop close ties with the State of nationality of his father, in particular if he lives abroad. This seems to me to be the background of the Danish and Swedish legislation. Perhaps this argument is behind the exception made in respect of children born out of wedlock in some other countries as well.

b) In countries where a man can recognize a child, even in cases where this is not in conformity with the biological truth, there is a certain danger that recognition, if it does have nationality consequences ex lege, can be abused e.g. to circumvent procedures and restrictions in respect of international adoption. This is e.g. the case in the Netherlands. The Netherlands Nationality Act of 1985 still mentions recognition and legitimation as grounds for acquisition of nationality (4 NET (1985)). Some years ago it was discovered that some Netherlands men recognized after having received money - foreign illegitimate minors in order to give them Netherlands nationality and therefore free access to the Netherlands. As a reaction to this discovery, the government of the Netherlands proposed to abolish recognition and legitimation as grounds for ex lege acquisition of nationality. This proposal was accepted by parliament and will come into force in 2003. It has to be mentioned, that this modification was heavily criticized in the legal literature ${ }^{38}$ inter alia because in most cases of recognition and legitimation the man involved really is the biological father of the child. Furthermore, the Public Prosecutors Office already has the ability to request the annulment of a recognition if the recognition violates public policy (ordre public).

37. See also 2 ICE (above, § 2.A.2.c).

38. Against a modification of Art. 4 Nationality Act: Matjaz Tratnik, 'Een overheid, die spoken ziet', 63 Nederlands Juristenblad (1989), 296-298. See also M.J.C. Koens, 'Nationaliteit en Nederlanderschap', in Pitlo/Gr. van der Burght/M. Rood-de Boer, Personen-en familierecht, (Gouda Quint, 1998), 13. 
c) Finally, it has to be admitted that the acquisition of a nationality ex lege based on recognition or legitimation sometimes can be problematic for completely different reasons. It may happen that an older foreign minor acquires a certain nationality because of the recognition or legitimation without his own consent in respect of the nationality consequences. This leads to problems if the acquisition of the new nationality causes the loss of his previous nationality (usually the nationality of the mother). Of course, one of the requirements for recognition or legitimation is normally the consent of the mother of the child (in the Netherlands until the child reaches the age of 16) as well as the consent of the child (in the Netherlands if he is older than 12 years). However, one has to realize that the consent is focussed on the establishment of a family relationship between the child and the man involved. The nationality dimension of a recognition is in many cases not taken into account. Furthermore, potential nationality consequences should not be the reason to give or to refuse the required consent. In Austria, the Constitutional Court came to the conclusion that the acquisition of Austrian nationality ex lege by a foreign minor legitimated by an Austrian man constituted a violation of the Austrian constitution, inter alia because of the potential loss of another nationality (in that case, the nationality of Liechtenstein). ${ }^{39}$ This decision made a modification of Austrian nationality law necessary. Therefore, since $1985^{40}$ Austrian nationality is exclusively acquired ex lege by legitimation if the child who has already reached the age of 14 gives his consent and the legal representative does also (see above $\S 2$.A.2.b).

Although all of the arguments mentioned have some value, I would submit that one should study all possibilities to give children born out of wedlock as far as possible, the same position as children born in wedlock. If for one of the reasons just mentioned, a legislator wants to restrict the transmission of nationality iure sanguinis a patre in case of children born out of wedlock, the restriction should only be as wide as necessary in order to reach the goal of that restriction.

If, for example, a country does not give ex lege nationality consequences to recognition of a minor because of potential circumvention of the rules on international adoption, it should be possible to acquire the nationality if evidence on the biological truth of the recognition is presented. If a country does not link ex lege acquisition of nationality to a recognition because of the fact that a child may lose another nationality already acquired iure sanguinis a matre, it should be explored whether an ex lege acquisition linked with an opting out possibility perhaps would bring the child in question closer to

39. Decision of 12 June 1984, Bundesgesetzblatt Nr. 375/1984.

40. See Staatsbürgerschafts-Novelle 1985, Bundesgesetzblatt 1985, 568. Compare on that modification Gerard-René de Groot, Staatsangehörigkeitsrecht im Wandel, 145, 146; Hans Pfersmann, 'Reforme und Probleme im Staatsbürgerschaftsrecht', Osterreichische Juristenzeitung (1985), 76, 77; Michael Schwimann, 'Österreich. Emeute Änderung des Staatsbürgerschaftsrechts' Das Standesamt (1986), 110116. 
the position of a child born within wedlock than the possibility to acquire the nationality via the lodging of a declaration of option.

Not to attribute the nationality of the father to a child born out of wedlock in case of birth abroad because such a child probably will not develop a genuine link with the country of nationality of the father seems to me, in all cases, a differential treatment of children born out of wedlock in comparison to those born within wedlock which can not be supported by convincing arguments. ${ }^{41}$

\section{B. ADOPTED CHLDREN ${ }^{42}$}

Acquisition of nationality by adoption is not mentioned in Art. 6 ECN as a desirable ground for acquisition of nationality ex lege. It is only mentioned as a ground for privileged acquisition. This is remarkable because on the other hand, Art. 7 (g) ECN does mention that a nationality act may provide that a nationality is lost by the adoption of children, if the nationality of the adopting parents is acquired.

Nevertheless, many countries mention adoption as a ground for acquisition of nationality ex lege (9 BEL; 6 GER; 27 (1) GRE; 13 MOL; 3 ITA; 5 NET; 13 POL; 5 POR; 6 SLK; 19 (1) SPA; 3 SWE; 7 SWI). Most of these countries require that the adoption involved was realized during the minority of the child. However, in some countries the age limit is lower: so e.g. 2a DEN; 2a ICE; 1a NOR; 3 SWE (12 years). See also 7 SLN.

According to the Belgian legislation, adoption is a ground for acquisition, but if the adopted child was born abroad and the Belgian adoptive parent(s) also, exceptions exist (9 BEL).

Some countries only provide for nationality consequences of adoption when the adoption order was made by a court, or by authorities of the country involved (so e.g. 1 (6) UK; compare also $11 \mathrm{IRE}$ ). However, an increasing number of nationality codes provide for the possibility that a foreign adoption order has nationality consequences if this foreign adoption order is recognized because of rules of private international law. In some countries, a special reference is made to the Hague Adoption Convention of 29 May 1993 (See 5 (2) and (3) NET, 3 (2) SWE). Compare as well 2a ICE.

41. Children born abroad after the death of their father who was married to the mother do acquire - as far as I can see - in principle the nationality of their father but are in a comparable position.

42. Compare Hellmuth Hecker, Einfluß der Adoption auf die Staatsangehörigkeit. Eine rechtsvergleichende Darstellung der Regelungen in 175 Staaten, (Standesamt, 1985), 153-163 and Gerard-Rene de Groot, Staatsangehörigkeitsrecht im Wandel, 196-199. 
In respect of adoption, one has to realize that many countries only know full adoption, which replaces completely the pre-existing legal family ties of the child with the original parents by a family relationship with the adoptive parents. Some countries provide (in most cases as an alternative: so e.g. France and Portugal) for a weak adoption (also called 'simple adoption'), which creates a family relationship with the adoptive parents, but does not disrupt all legal ties with the original parents. This socalled 'weak' adoption often lacks nationality consequences (so expressly 21 FRA), whereas the full adoption has these consequences (so 20 (2) juncto $18 \mathrm{FRA}$; see also 5 POR restricted to full adoption).

In Luxembourg full adoption of minors has ex lege nationality consequences (2 (1) LUX) whereas a weak adoption only has these consequence in the case of minors who are stateless or lose their original nationality as a result of foreign legislation (2 (2) LUX).

\section{ACQUISITION IURE SOLI (BY BIRTH ON THE TERRITORY) \\ 1. Strict Ius Soli}

Of the countries studied for this report only Ireland (Sect. 6 (1)) applies ius soli. Until 2001 this was a strict ius soli: by birth on Irish territory a child acquired the nationality of Ireland. An exception was exclusively made for children of aliens entitled to diplomatic immunity (6 (4) IRE). This exception conforms to the Optional Protocol to the Vienna Conventions on Diplomatic relations ${ }^{43}$ concerning Acquisition of Nationality and the Optional Protocol to the Vienna Conventions on Consular relations ${ }^{44}$ concerning Acquisition of Nationality. Compare as well the Portuguese legislation (see below Par. III, 1). In 2001 Sect. 6 was amended. Sect. 6 (1) now states, that every person born in the island of Ireland is entitled to be an Irish citizen. Sect. 6 (2) (a) provides that a person born in the island of Ireland is an Irish citizen from birth if he or she does, or if not of full age has done on his or her behalf, any act which only an Irish citizen is entitled to do. The exception made for children of aliens entitled to diplomatic immunity is maintained (6 (4) (a)). Sect. 6 (4) (b) IRE provides for another exception in case of children born to a non-national on a foreign ship or in a foreign aircraft.

Remarkable is the Luxembourgian provision where 4 (1) LUX states since 2001, that birth in Luxembourg before 1 January 1920 establishes the possession of nationality of Luxembourg. This provision, however, is in particular important for the proof of

43. Concluded in Vienna 18 April 1961, UNTS vol. 500, 223.

44. Concluded in Vienna 24 April 1963, UNTS vol. 596, 469. 
nationality and does not manifest the desire to introduce ius soli-acquisition in the Luxembourgian legislation as a basic principle.

\section{Acquisition Iure Soli by Children, who would Otherwise be Stateless ${ }^{45}$}

According to Art. 6 (2) ECN, each State Party shall provide in its internal law for its nationality to be acquired by persons bom on its territory who would otherwise be stateless. This rule is repeated in Recommendation R 99 (18) in Part II A sub b, already mentioned above. The nationality of the country of birth has to be attributed either ex lege at birth or subsequently to children who remained stateless upon application.

Of the countries included in this publication, Belgium (10 (1) BEL), Czech Republic (3 CZE); Finland (1 (4) FIN), France (19-1 FRA), Greece (1 (2) GRE), Hungary (3 (3) (1) HUN), Italy (1 (1) (b) ITA), Luxembourg (1 (3) LUX), Moldova (11 (1) (b) and (c) MOL), Poland (11 (2) POL), Portugal (1 (1) (d) POR), Slovakia (5 (1) (b) and (c) juncto 5 (2) SLK); Slovenia (9 SLN); Spain (17 (1) (c) SPA) opted for the first mentioned possibility. Ireland does the same since the amendment of the nationality legislation in 2001 (6 (3) IRE). In most of these countries, a provision also can be found dealing with the loss of nationality if it is later discovered that the person involved was not stateless. ${ }^{46}$ According to Belgian law, Belgian nationality is also acquired by a person born on Belgian territory who becomes stateless during his minority. The Czech Republic provides that Czech nationality is acquired by a potential stateless child born on the territory of the republic if at least one parent has his permanent residence there.

Since 2001 the Luxembourg provision is restricted to children born in Luxembourg without another nationality because of the fact that their parent(s) are stateless. ${ }^{47}$

\section{Acquisition Iure Soli by Children, whose Parent(s) have Domicile/Residence within} the Territory of the State involved (Ture Domicilii) ${ }^{48}$

It was mentioned above that Ireland attributed until 2001 its nationality to all children born on Irish territory. Until 1983 this was also the case in the United Kingdom. However, since the British Nationality Act of 1981 entered into force on I January 1983 , s. 1(1) provides that a person born in the United Kingdom after that date shall be a British citizen if at the time of its birth his father or mother is (a) a British citizen or

45. Gerard-René de Groot, Staatsangehörigkeitsrecht im Wandel, 204, 205.

46. See Gerard-René de Groot, 'Loss of nationality', Par. 11.2. Nevertheless, there are also countries where this ground for acquisition is not linked with a conditional ground for loss. That is, for example, the case in Moldova. Art. 11 (2) MOL provides that a foundling found on the territory of Moldova shall be considered as a citizen, unless otherwise is proven before the age of 18 . The provision of Art. 11 (1) (b) in favour of potential stateless children is not amended in a similar way.

47. Compare below § 3.B.

48. See Gerard-René de Groot, Staatsangehörigkeitsrecht im Wandel, 203, 205-207. 
(b) settled in the United Kingdom. Section 1(8) juncto 50(2) indicates that references in the British Nationality Act to a person being settled in the United Kingdom are references to his being ordinarily resident in the United Kingdom without being subject under the immigration laws, to any restriction on the period for which he may remain.

Since 1 January 2000, par. 4 (3) of the German Nationality Act provides that a child of foreign parents borm in Germany acquires iure soli German nationality if one parent has, at the time of the child's birth, his legal habitual residence in Germany for at least eight years, or is entitled to stay permanently ('Aufenthaltsberechtigung') or has for at least three years an unlimited residence permit ('Aufenthaltserlaubnis'). It has to be mentioned that par. $29 \mathrm{G}$ provides inter alia that a child who acquired German nationality in this way and also possesses a foreign nationality has to lodge a written declaration with the German authorities before reaching 23 years, stating whether he wants to retain the German or the foreign nationality. If he chooses in favour of the foreign nationality, German nationality is lost. If no declaration is made before reaching 23 years, German nationality is lost as well. Before reaching 21 years, an application can be made to receive a permit of retention of the foreign nationality along with German nationality.

This ground for loss is remarkable: after having possessed German nationality for his whole life, a person can lose German nationality even in cases where the person involved continues to live in Germany. In my opinion this ground for loss is not covered by any provision of art. $7 \mathrm{ECN}^{49}$

If we set aside the just criticized par. $29 \mathrm{G}$, the British and German provisions are an inspiring attempt to indicate that a certain group of persons bom on the territory of a state will quite likely develop such close ties with the state involved that acquisition of nationality ex lege is justified. ${ }^{50}$ Also compare the option rights mentioned in $\S$ 3.A, 3.C and 3.J and the ex lege acquisition of nationality by the second generation born on the territory of a country (below \& 2.C.4).

49. In particular, it can not be classifjed as loss because of lack of a genuine link, because of the fact that the nationality was attributed because of the assumption that the child born on German territory will develop sufficient ties with Germany. To deny a genuine link because of the fact that the person involved also possesses another nationality and does not renounce that other nationality is not realistic in case of residence in Germany.

50. See also $\S 2 . \mathrm{E}$. 


\section{Acquisition Iure Soli by Children, whose Parent(s) was (were) also born on the} Territory of the State involved (double ius soli) (1) $^{51}$

\section{a. Strict Application of the Double Ius Soli Principle}

In some countries, nationality is attributed ex lege to children whose parent(s) was (were) also born on the territory of the state involved. This ground for the acquisition of nationality was introduced for the first time by France in $1851^{52}$ and is often described as acquisition by double ius soli. The background to this rule is that the second generation of persons born on the territory of a state (being the third generation living there) are deemed to have such a close link with the state involved that neither the persons involved nor the authorities of the country of birth should have the possibility to prevent the acquisition of the nationality of the country of birth. The rule is still part of the French Code civil (19-3 FRA) and can also be found in Spain (17 (1) (b) SPA).

In this context, another remarkable Austrian provision has to be mentioned. 8 (2) AUS provides that, subject to proof to the contrary, a person is deemed to be Austrian if he is born in Austria and one of his parents was also born there. In the case of birth out of wedlock the place of birth of the mother is decisive.

\section{b. A Residence oriented Variation on the Double Ius Soli Principle}

Article 3 (3) of the Netherlands Nationality Act contains a rule which comes very close to the traditional French double ius soli rule. 3 (3) NET provides that a child shall be a Netherlands national if it is born to a father or mother who has his/her main habitual residence ('hoofdverblijf' in the sense of 'feitelijke woonstede') in the Netherlands, the Netherlands Antilles or Aruba at the time of its birth, and if this father or mother was born to a father or mother residing in one of these countries at the moment of the birth of her child, provided the child has also his main habitual residence in the Netherlands. This is the so-called third-generation rule. Article 3 (3) does not contain a strict ius soliregulation. The provision does not demand that the child be born on Netherlands soil, only that the father or mother resides in the Kingdom of the Netherlands.

11 (1) BEL provides that a person who is born in Belgium as the child of a foreigner who also was born in Belgium and who had his main habitual residence in Belgium for at least 5 years of the 10 years directly preceding the child's birth acquires Belgian nationality ex lege. A similar rule applies in the case of adoption (11 (2) BEL).

51. See Gerard-René de Groot, Staatsangehörigkeitsrecht im Wandel, 206-208.

52. See Gerard-René de Groot, Staatsangehbrigkeitsrecht im Wandel, 77, 399. 


\section{CHILDREN FOUND ON THE TERRITORY ${ }^{53}$}

Article 6 (1) (b) ECN prescribes that a foundling found in the territory of a state has to acquire the nationality of that state if he would otherwise be stateless. The wording of this provision is drawn from art. 1 of the 1961 Convention on the Reduction of Statelessness. This provision is not restricted to new-born infants, but applies to every child in the sense of the Convention, i.e. every person below the age of eighteen years unless, under the law applicable to the child, majority is attained earlier (see art. 1 sub c). If later, but during his minority, the child's parents are discovered, and the child derives a nationality from (one of) these parents or acquired a nationality because of his place of birth, the nationality acquired because of the foundling provision may be lost. This is allowed by art. 7 (1) (f) ECN.

The nationality legislation of several countries is in conformity with art. 6(1) (b) ECN. For example, art. 3 (2) NET provides that a child shall be deemed to be the child of a national if he was found on the territory of the Netherlands, the Netherlands Antilles or Aruba or on a ship or aircraft registered in one of these countries. In this case, he obtains the Netherlands nationality on the basis of art. 3 (1) NET. This presumption (praesumptio iuris sanguinis) is not absolute. If it becomes apparent within five years from the day on which the child was found, that he does not possess Netherlands nationality, but exclusively a foreign nationality by birth, the nationality of the Netherlands will be lost. But in the case of potential statelessness, he keeps this nationality.

Belgium (10 (2) BEL), France (19 FRA), Moldova (11 (2) MOL), Portugal (1 (2) juncto 14 POR), Slovenia (9 SLN); Spain (17 (1) (d) juncto 17 (2) SPA) and Switzerland (6 (3) SWI) have similar regulations, but provide that the nationality acquired by a foundling is lost if, during his minority, it is discovered that he is the child of foreign parents and would not become stateless. These provisions correspond precisely with art. 6 (1) (b) ECN. Also compare 11 (2) POL.

In Austria (8 (1) AUS), Czech Republic (5 CZE); Denmark (1 (2) DEN), Finland (1 FIN), Germany (4 (2) GER), Greece (cf. 1(2) GRE), Hungary (3 (3) (2) HUN); Iceland (1 ICE), Ireland (10 IRE), Italy (1 (2) ITA); Luxembourg (1 (2) LUX), Norway (1 NOR); Slovakia (5 (2) (b) SLK; Sweden (2 SWE) and the United Kingdom (1 (2) UK) nationality is aiso lost by a foundling if his descent is discovered after majority. That conflicts with the ECN. ${ }^{54}$

53. See Gerard-René de Groot, Staatsangehörigkeitsrecht im Wandel, 209, 210.

54. It has to be mentioned, that with respect to Art. 6 (1) (b) ECN, Austria made a declaration with the following formulation: 'Austria declares to retain the right that foundlings found in the territory of the Republic are regarded, until proven to the contrary, as nationals by descent only if they are found under 
In some countries, the provision on foundlings only applies to new born infants (so: 8 (1) AUS; 10 (2) BEL; 10 IRE; 1 (2) UK). That also does not conform with the ECN. The Czech Republic limits the provision for found children to persons under 15 years. In view of the $\mathrm{ECN}$, the provision should apply to all persons younger than 18 years.

5 (2) EST, according to which a child of unknown parents found in Estonia is declared on application of his guardian or a guardianship authority by a court decision to have acquired Estonian nationality by birth unless the child is proved to be a national of another state, is remarkable. The obvious declaratory character of the court decision and the absence of any discretionary power of the court leads to the conclusion that this regulation is in conformity with the ECN.

\section{E. ACQUiSITION BECAUSE OF BIRTH ON THE TERRITORY AFTER A CERTAIN PERTOD OF RESIDENCE ${ }^{55}$}

Children born in France to foreign parents born abroad acquire French nationality ex lege when they reach the age of majority (21-7 FRA). They may lodge a declaration of option in order to acquire French nationality earlier. From the age of 16 years they can make such a declaration themselves; their legal representative may lodge an application with the consent of the minor once the minor has reached the age of 13 years. The applicant has to fulfil the following conditions: he/she must reside in France and must have lived there for at least five years. ${ }^{56}$

This should be compared with the British and German grounds for acquisition mentioned above under $\S 2 . C .3$ and the option rights described in $\S 3 . A$ and 3.C.

\section{F. ACQUISITION BECAUSE OF MILITARY SERVICE OR STATE SERVICE}

According to Austrian nationality law, an alien acquires ex lege Austrian nationality by accepting an appointment as an ordinary professor at an Austrian university. This is provided by art. 6 (4) Austrian constitution (Bundesverfassungsgesetz) ${ }^{57}$ Compare also in this context the legislation of the Vatican.

the age of six months.' It is obvious, that this is not a declaration with an interpretative character but a reservation. The aim of the Convention is also to cover cases where older children are 'found' and the circumstances do not allow for the discovery of their identification, in particular the descendance of the children involved. An early draft of the European convention had included a provision on foundlings inspired by the above mentioned provision of the British Nationality Act restricted to new-born infants. Later the provision on foundlings was revised. The final text is therefore definitely not restricted to very young children.

55. See Gerard-René de Groot, Staatsangehörigkeitsrecht im Wandel, 213, 214.

56. See also 21-11 FRA.

57. Also see $25 \mathrm{~A}$. 
French nationality can, if certain conditions are fulfilled, be acquired by a person born in France who enters the French army (21-9 FRA).

Ex lege nationality consequences of an appointment in state or military service or the grant of an option right based on such an appointment implies a decentralized decision on the acquisition of nationality by authorities which normally have no competence in nationality matters. Although civil or military service of a state implies in principle a close link with the state involved, which justifies the possession of the nationality of that state, it is understandable that almost all states prefer to have these links controlled by authorities which are-inter alia - specialized in nationality matters.

\section{G. ACQUISITION BECAUSE OF CONYNUUOUS TREATMENT AS A NaTIONAL}

In Spain the possession and continuous use of Spanish nationality for 10 years in good faith and based on a title registered in the civil register is cause for consolidation of the nationality if the title for the acquisition involved is annulled (18 SPA). In other words, continuous treatment as a national is, in case of good faith of the person involved, a ground for acquisition of nationality. ${ }^{58}$

\section{H. ACQUisition BECAUSE OF MARRJAGE ${ }^{59}$}

Marriage as a ground for acquisition of a nationality ex lege disappeared completely in the legislation of the states which are included in this contribution. This is in conformity with art. 4 (d) ECN which provides that neither marriage nor the dissolution of a marriage between a national of a State Party and an alien, nor the change of nationality by one of the spouses during marriage, shall automatically affect the nationality of the other spouse.

In the past, almost all nationality acts applied the so-called unitary system ${ }^{60}$ of nationality within a family. A foreign woman who married a national generally acquired the nationality of her husband. By marrying a foreigner a woman lost her original nationality. ${ }^{61}$

58. Compare also 29 SWI (privileged naturalization). See also the option rights described in $\$ 3 . \mathrm{G}$.

59. See Gerard-René de Groot, Statisangehörigkeitsrecht inz Wandel, 308-311.

60. In French 'système unitaire'. See Bernard Dutoit, La nationalité de la femme mariée, Band I: Europe (Geneva, Librairie Droz, 1973); Band II: Afrique (Geneva, 1976); Band III: Amérique, Asie, Océanie (Geneva, 1980) and Bermard Dutoit, Nationalité et mariage: leur interaction dans le droit comparé de la nationalite', in Verwilghen, Nationalité et statut persomel, 443-474.

61. See for example around 1900: Austria (Par. 32 ABGB), Belgium (art. 17 sub $3 \mathrm{Cc}$ ), Denmark, Germany (art. 13 Act 1870), Greece (art. $25 \mathrm{Cc}$ ), Luxembourg (art. 17 sub $3 \mathrm{Cc}$ ), Netherlands (art. 5 Act 1892), Spain (art. $22 \mathrm{Cc}$ ), Sweden (art. 6 Act 1894), Switzerland, Turkey (compare: art. 7 Act 1869), United Kingdom (Sect. 10 sub 1 Act 1870). 
Nevertheless, in some countries some provisions still deal with the position of married women. In France art. 21-1 underscores that a marriage does not affect the acquisition or loss of French citizenship. A similar provision can be found in the Greek nationality act (Art. 4). In Ireland even two provisions deal with this issue. Section 22 IRE provides:

1. The death of an Irish citizen shall not affect the citizenship of his or her surviving spouse or children.

2. Loss of Irish citizenship by a person shall not of itself affect the citizenship of his or her spouse or children.

And s. 23 IRE underscores:

A person who marries an alien shall not, merely by virtue of the marriage, cease to be an Irish citizen, whether or not he or she acquires the nationality of the alien.

These provisions can be understood as a reaction to the previous legal situation, but are, strictly speaking, superfluous. ${ }^{62}$

\section{ACQUISITION BY EXTENSION OF THE ACQUISITION OF NATIONALITY BY A PARENT ${ }^{63}$}

Most countries provide that, under certain conditions, children of a person who acquires the nationality of the country also acquire this nationality, if they are still minors. The specific conditions and details of the different extension regulations will not be elaborated in this publication. A large variety of conditions for an extension of acquisition can be observed. ${ }^{64}$ The content of the provisions on the extension of the acquisition of nationality depends, inter alia, on the power which a state decides to give parents in respect of the determination of the nationality position of their minor children. ${ }^{65}$

\section{J. PERSONS OF A CERTAIN ETHNicITY}

A foreigner who is recognized in Germany as a refugee or expellee of German ethnicity in the sense of art. 116 of the German constitution ('Grundgesetz') acquires German nationality, at the moment of the delivery of the certificate of recognition ( 7 GER). The text of art. 116 Constitution reads - in English translation - as follows:

62. See furthermore the option rights mentioned in $\$ 3 . H$.

63. See Gerard-René de Groot, Staatsangehörigkeitsrecht im Wandel, 271-273.

64. Compare e.g. 12 BEL; 6 and 13 DEN; 22-1 FRA; 10 GRE; 2 (3) LUX; 14 ITA; 2 (3) LUX; 6 and 11 NET.

65. Compare the remarks made above in § 2.A.1. 
Unless otherwise provided by law, a German within the meaning of this Constitution is a person who possesses German nationality or who has been admitted to the territory of Germany within the frontiers of 31 December 1937 as a refugee or expellee of German ethnicity or as the spouse or descendant of such a person. ${ }^{66}$

This provision should be understood in view of the history of Germany in the 20th century but is problematic in view of Art. 5 (1) ECN which forbids, inter alia, any discrimination in respect of the acquisition or loss of nationality based on race or ethnicity. ${ }^{67}$

K. VARIA

A stateless child under guardianship of citizens of Moldova acquires Moldovan nationality ex lege. The same applies if one of the guardians is a Moldovan citizen and the other stateless (15 (1) and (2) MOL). Compare this with the option rights mentioned in $\S 3 . D$.

\section{§3. Acquisition by Declaration of Option ${ }^{68}$}

This part will discuss which persons are entitled in the various countries to acquire, under certain conditions, the nationality of the country involved by lodging a declaration of option. The details of the conditions can not be elaborated nor will the precise option procedure be described. The object is only to present a list of categories of persons, who are privileged in some states in respect of the acquisition of nationality by the grant of a right of option. Option rights of a transitory character (e.g. in favour of the children of female nationals born before the nationality legislation of the country of the mother implemented the equal treatment of men and women) are not mentioned.

It is important to stress that there are at least two distinct types of options. According to the law of some countries, a declaration of option can be made orally without any formality. ${ }^{69}$ Of course the declaration has to reach the competent authorities. Normally these authorities will make an official document, which will be signed in order to prove the declaration, but if such a document does not exist, the declaration can be proved by any other means. If a declaration was made, but not all the conditions giving a right to opt were fulfilled, the nationality is not acquired. If all conditions were fulfilled and the

66. Art. 116 Grundgesetz: 'Deutscher im Simne dieses Grundgesetzes ist vorbehaltlich anderweitiger gesetzlicher Regelung, wer die deutsche Staatsangehörigkeit besitzt oder Vertriebener deutscher Volkszugehơrigkeit oder als dessen Ehegatte oder Abkömmling in dem Gebicte des Deutschen Reiches nach dem Stande vom 31. Dezember 1937 Aufnahme gefunden hat."

67. Compare the Greek provisions mentioned in $\S 3 . \mathrm{K}$.

68. Gerard-René de Groot, Staatsangehörigkeitsrecht im Wandel, 215, 216.

69. This type of option still exists in the Netherlands at the moment but will be replaced in 2003 by the second type of option rights. 
declaration can be proved, although no document exists, the nationality is nevertheless acquired. The authorities do not have the possibility to avoid the acquisition of nationality because of for example reasons of public policy or state security.

In some other countries, a person who uses his right of option must make a written declaration. The authorities control whether all the conditions are fulfilled, but they are also able to reject the option for reasons of public security or lack of integration (defaut d'assimilation).$^{70}$ It is obvious that this kind of option is much weaker than the first category mentioned. It is therefore not surprising that, generally speaking, countries which have this second type of option rights often grant this right to considerably more persons than countries where the first type of option rights exists. One could also describe the second type of option rights as a quick naturalization procedure where the discretion of the authorities to refuse the acquisition of nationality is limited.

Some countries do not use the term 'option rights', but provide for the possibility to register as a citizen if certain requirements are met. If the authorities do not have any discretion in respect of the registration, such a right to register as a citizen is in fact an option right of the first mentioned category. If there is discretion by the authorities, it can be classified as an option right of the second category.

In this context it also has to be mentioned that a couple of countries use the construction of a legal entitlement to naturalization ('Einbürgerungsanspruch'): if certain conditions are fulfilled naturalization has to be granted on the application of the person involved. The authorities' discretion is reduced to zero. Such an entitlement comes close to the option rights of the first mentioned category. If the naturalization can still be refused for reasons of public policy or similar general reasons, the entitlement can be compared with the option rights of the second category.

\section{A. PERSONS BORN ON THE TERRITORY ${ }^{71}$}

Children born in Portugal to foreign parents who have been resident in Portugal for at least six years, who are nationals of a country whose official language is Portuguese or, in other cases, at least ten years (1 (1) (c) POR) acquire Portuguese nationality by making an option declaration.

Section 1 (3) UK grants a right to register as a British citizen to a person born in the United Kingdom if, while he is a minor his father or mother becomes a British citizen or settles in the United Kingdom. Section 1 (4) UK gives a right to register to a person born in the United Kingdom after he has attained the age of ten years if, as regards each

70. (compare also 12bis (2) BEL; 6 ITA; 22 LUX; 6 NET; 9 POR).

71. See Gerard-René de Groot, Staatsangehörigkeitsrecht in Wandel, 216-221, 229, 235. 
of the first ten years of that person's life, the number of days on which he was absent from the United Kingdom in that year does not exceed 90.

According to Netherlands nationality law, persons who were born in the Netherlands and have their lawful, main habitual residence there may acquire Netherlands nationality by making a declaration of option if they are over the age of majority and have lived in the Netherlands since birth (6 (1) (a) NET).

A similar provision can be found in Italy (4 (2) ITA, but there a declaration of option has to be made within one year after having attained the age of majority.

A child born in Belgium can acquire Belgian nationality by a declaration of option made by the parents before the child reaches 12 years. The parents must have had their main habitual residence in Belgium for ten years before making this declaration (11bis BEL). A similar rule applies to adopted children born in Belgium. After having attained the age of 18, a person born in Belgium has another option right (12bis (1) (1) BEL). ${ }^{72}$

In Luxembourg, there is an option right for persons born in Luxembourg which has to be used between the age of 18 and 25. During the year prior to the declaration of option the person involved must have had his habitual residence in Luxembourg; in total he must have lived there for at least 5 years (19 (1) LUX).

In Ireland there is already a general entitlement to acquisition. Compare also the French provision on ex lege acquisition, mentioned in Part II, 5 (21-7 FRA; Cf 21-11 FRA) and the provision described in Part II, 3c. See furthermore 6 (4) (e) ECN.

\section{B. STATELESS PERSONS BORN ON THE TERRITORY ${ }^{73}$}

Article 6 (2) ECN prescribes that a state which does not grant its nationality to potential stateless persons born on its territory ex lege has to grant the nationality subject to only one or both of the following conditions: a) lawful and habitual residence on the territory of the state involved for a period not exceeding five years immediately preceding the lodging of the application, and b) absence of a conviction for a serious offence.

It was already mentioned above (Part II, 3b), that a considerable number of countries provide for an ex lege acquisition in case of potential stateless children born on the territory of that state.

72. Compare also 13 (1) juncto 14 and 15 BEL.

73. See Gerard-René de Groot, Staatsangelı̈rigkeitsrecht im Wandel, 221, 222, 235. 
In the Netherlands, stateless persons can opt for Netherlands nationality provided they fulfil the conditions laid down in art. 6 (1) (b) which provides that the alien has to be bom on Netherlands territory and since his birth he must have had his main habitual residence in the Netherlands, the Netherlands Antilles or Aruba for at least three years and he has been stateless since his birth.

In Sweden a stateless child born in Sweden who lives there in possession of a permanent residence permit can opt for Swedish nationality. The declaration of option has to be lodged before the child reaches the age of 5 years $(6 \mathrm{SWE})$.

In Austria stateless persons bom in Austria and living there at least 10 years (of which 5 years immediately preceding the naturalization) have, if they fulfil certain legal requirements, an entitlement to naturalization (14 AUS).

Compare for the United Kingdom the provisions described in the previous paragraph for persons born in the UK, juncto Par. 3 of Schedule 2 British Nationality Act. See furthermore art. $6(4)(\mathrm{e})$ and $(\mathrm{g}) \mathrm{ECN}$.

\section{PERSONS Who FULFILl CERTAIN RESIDENCE REQUIREMENTS ${ }^{74}$}

In Belgium, a foreigner who has his main habitual residence there for seven years and who possesses a permanent residence permit or a permit to settle there permanently can acquire Belgian nationality by making a declaration of option (12bis (1) (3) BEL). ${ }^{75}$

In the Netherlands foreigners legally having their main habitual residence there for more than 15 years can acquire Netherlands nationality by declaration of option (6 (1) (h) NET).

In Sweden children younger than 18 years have an option right if they live in Sweden for 5 years (stateless persons: for three years) and possess a permanent residence permit. Children older than 12 years have to give their consent ( $7 \mathrm{SWE}$ ).

According to German legislation, foreigners living in Germany longer than 15 years have under certain additional conditions, a legal entitlement to naturalization (Par. 86 Aliens Act ('Ausländergesetz')). In Austria, foreigners can under certain conditions have a legal entitlement to naturalization after 30 years of residence (12 (a) AUS). See furthermore art. 6(4) (f) ECN.

74. See Gerard-René de Groot, Staatsangehörigkeitsrecht im Wandel, 236.

75. See also 13 (2) juncto 14 and 15 BEL. 


\section{PERSONS UNDER GUARDIANSHIP OR PARENTAL AUTHORITY OF A NATIONAL ${ }^{76}$}

A foreign child who is under joint custody of a parent and the partner of this parent or under the custody of two guardians (one of them possessing Netherlands nationality) can opt for Netherlands nationality after the Netherlands national involved has cared for him and educated him for at least three years before the age of majority (6 (1) (d) NET).

Spain provides for an option right for all foreign minors who are or were under the parental authority of a Spanish national. For a minor younger than 14 years the legal representative has to opt. In that case, the consent of the Spanish authorities is required and will be given if the option is in the interest of the minor. A minor older than 14 years can opt assisted by his legal representative. After having attained the age of majority this option right still exists for two years (20 SPA). ${ }^{77}$

This option right does not correspond with any category of persons whose acquisition of a nationality should be facilitated according to art. 6 (4) ECN.

\section{E. Children of a National}

1. Children who did not acquire Nationality because of an Exception allowed by Art. 6 (1) (birth abroad or out of wedlock) ${ }^{78}$

Article 6 (4) (b) ECN prescribes that states must facilitate of the acquisition of nationality by children of one of its nationals falling under the exceptions of art. 6 (1) (a) ECN (i.e. children who did not acquire the nationality of a parent because they were born abroad or born out of wedlock). Of course, only in countries which make use of these exceptions can option rights for these categories of children be found.

In the Netherlands, a recognized or legitimized child of a Netherlands father has the opportunity to acquire Netherlands nationality by confirmation of a declaration of option after the father has cared for and educated him/her ("verzorging en opvoeding") for a period of three years (6 (1) (c) NET). Also compare this with the complicated regulation of the entitlement to naturalization of the child born out of wedlock of an Austrian father (12 (d) and 17 (1) (3) juncto 10 (1) (1-8) and (2) AUS).

According to Swedish legislation, a Swedish father can register his children born abroad outside of wedlock as Swedish citizens before they reach the age of 18 ( 5 SWE).

76. See Gerard-René de Groot, Slaatsangehörigkeitsrecht in Wandel, 223.

77. Cf, also 21-12 (2) (1) F and 15 MOL (see above $\$ 2 . \mathrm{K}$ ).

78. See Gerard-René de Groot, Staatsangehörigkeitsrecht im Wandel, 236. 
3a FIN provides that the child born out of wedlock of a Finnish father has an option right to Finnish nationality if a) the father is still Finnish, b) the father has (joint) custody; c) the child resides in Finland and d) the child is younger than 18 years and not married.

A special provision can be found in Spain, where 17 (2) SPA provides that the descent from a Spanish national established after majority creates an option right to Spanish nationality to be used within two years after the establishment. The same applies if the birth in Spain was discovered only after majority.

Belgian legislation grants an option right to the child older than 18 years born abroad of a Belgian national (12bis BEL). If the child born abroad is only the adopted child of a Belgian national and the child did not yet receive Belgian nationality, the Belgian legislation provides for an option right to be used between the age of 18 and 22 (13 (3) juncto 14 and $15 \mathrm{BEL})$.

The child born abroad of one Slovenian parent between the age of 18 and 23 has a comparable option right ( 6 SLN; see for adopted children: 7 SLN).

2. Other Children (parent acquired the nationality of the state involved after the child's birth)

In most countries, (minor) children often acquire the nationality of the country if one of their parents acquires this nationality (see above $\S 2$.I). In countries where this is not the case and for cases where the conditions in the legislation are not met, (minor) children sometimes have a right of option to the nationality involved if certain requirements are met. See e.g. 12bis (1) (2) BEL; 2 POR.

If the parents of a child who has already reached the age of majority acquire the nationality of Luxembourg the child gets an option right to be used between the age of 18 and 25. During the year prior to the declaration of option the person involved must have had his habitual residence in Luxembourg; in total he must have lived there for at least 5 years (19 (6) LUX). Compare further with art. 6 (4) (c) ECN.

\section{F. FORMER NATIONALS ${ }^{79}$}

The facilitation of the acquisition of nationality by former nationals is very common. This is also described as the recovery of nationality. In many states their naturalization 
is facilitated (compare Art. $9 \mathrm{ECN}$ ), in some countries an option right is granted in addition if certain requirements are met. ${ }^{80}$

\section{G. Persons treated as Nationals ${ }^{81}$}

In a couple of countries, persons treated as nationals for a certain period of time can acquire the nationality of the country involved by lodging a declaration of option, if they possessed the nationality in good faith. This is the case in Belgium after possessing Belgian nationality in good faith for a period of 10 years (17 BEL). A very similar rule exists in France (21-13 FRA). Compare this with the Spanish provision mentioned already above in § 2.G, 7 (18 SPA).

This option right does not correspond with any category of persons whose acquisition of a nationality should be facilitated according 6 (4) ECN.

\section{H. SPOUSES OF NATIONALS ${ }^{82}$}

In a considerable number of countries, spouses of nationals can acquire the nationality by declaration of option, if certain conditions are met.

22-2 FRA gives an option right to the foreign spouse of a French national after one year of marriage. The spouses must live together at the moment of the declaration of the option.

Most countries require that the couple must be married for three years before a declaration of option can be made by the foreign spouse of a national in order to acquire the nationality. This is the case in Ireland where the foreign spouse of an Irish national can opt for Irish nationality after three years from the date of marriage or the date on which the spouse became Irish. At the moment of the declaration of option, the marriage must still exist and the spouses must live together (8 IRE).

5 ITA also gives the foreign spouse of an Italian national the right to acquire Italian nationality by declaration of option after three years of marriage, provided the marriage still exists and there is no legal separation. If the spouses live in Italy the declaration of option can already be lodged after six months of marriage.

80. So e.g. 4 ICE; 6 FIN; $21-13$ FRA; 13 ITA; 26 LUX; 6 (1) (f) NET; 4 POR; 26 SPA; 10 and 13 UK. See also 58c AUS (option) and 12 (b) and (c) AUS (legal entitlement).

81. Gerard-René de Groot, Staatsangehörigkeitsrecht im Wandel, 226, 234.

82. Gerard-René de Groot, Staatsangehörigkeitsrecht im Wandel, 231, 236. 
According to Portuguese nationality law, the foreign spouse of a Portuguese national can acquire Portuguese nationality by declaration of option after three years of marriage (5 POR).

In Belgium the foreign spouse also has an option right after three years of marriage if the spouses were living together in Belgium. If the foreign spouse was already living in Belgium before the marriage the option can be lodged earlier (16 BEL). A very similar provision exists in Luxembourg (19 (3) juncto 21 LUX).

In the Netherlands the naturalization of a national's foreign spouse is facilitated by 8 (2) NET. After three years of marriage or registered partnership the foreign spouse can apply for naturalization, even if the spouses do not live in the Netherlands. It is remarkable that 8 (4) NET also facilitates the naturalization of unmarried persons who have lived with an unmarried Netherlands national for at least three years and have a permanent relationship other than marriage or registered partnership. 8 (4) applies to all cohabitation relationships in which the partners are not married, regardless of whether they are heterosexual or homosexual. The partners must have lived together in the Netherlands; cohabitation with a Netherlands national abroad does not entitle one to the facilitation of naturalization. In addition 6 (1) (g) provides that a foreigner who is married to a Netherlands national for 3 years and has his lawful, main habitual residence in the Netherlands may acquire Netherlands nationality by declaration of option. Compare furthermore 6 (4) (a) ECN.

\section{Persons educated IN THE TERritory of THE State INVOLVED ${ }^{83}$}

Article 6 (4) (f) ECN prescribes the facilitation of the acquisition of nationality by persons who have been lawfully and habitually resident on the territory of a state for a period of time beginning before the age of 18 as determined by the internal law of the State Party concerned.

According to Netherlands nationality law, these persons have an option right if they have lawfully had their main habitual residence in the Netherlands since at least four years of age $(6(1)(e)$ NET).

19 (4) LUX gives an option right to the foreigner who received his whole mandatory school education in Luxembourg. This right has to be used between the age of 18 and 25. During the year prior to the declaration of option the person involved must have had his habitual residence in Luxembourg; in total he must have lived there for at least 5 years (19 (4) LUX).

83. Gerard-René de Groot, Staatsangehörigkeitsrecht im Wandel, 230. 
In Sweden a person can opt for Swedish nationality between the age of 18 and 22, if he lives in Sweden with a permanent residence permit since the age of 13 (stateless persons since the age of 15) (8 SWE). A similar option right exists in Finland, Iceland and Norway for persons living there since the age of 16 for at least 5 years. The declaration of option has to be made between the age of 21 and 23. Stateless persons and persons who will lose their nationality by the acquisition of Finnish nationality can already opt after having reached the age of 18 ( 5 FIN; 3 ICE; 3 NOR). Denmark had a similar provision until 2000 . Since then, ${ }^{84}$ persons with a criminal record or charged with a criminal offence are excluded from this option right. The required period of residence is now 10 years of which 5 years within the last six years immediately before lodging the declaration of option. The option has to be lodged after attaining the age of 18, but before attaining the age of 23 ( $3 \mathrm{DEN})$.

In Germany a foreigner between 16 and 23 who was living there legally for at least 8 years and who received his education mainly in Germany has a legal entitlement to naturalization (Par. 85 Aliens Act ('Ausländergesetz')).

A person who had his main habitual residence in Belgium for at least one year together with a person who had the parental authority or custody over him before attaining the age of six can acquire Belgian nationality by a declaration of option which has to be lodged between the age of 18 and 22 (13 (4) juncto 15 and $16 \mathrm{BEL}$ ).

In France certain children educated there by a French national or a French institution or at least under circumstances which enabled them to visit French schools over a period of at least 5 years can acquire French nationality by lodging a declaration of option (21$12(2)(1)$ and (2) F).

\section{J. CHIEDREN ADOPTED BY NATIONAL ${ }^{85}$}

As we have already seen above, the facilitation of the acquisition of nationality by children adopted by one of its nationals is prescribed by art. 6 (4) (d) ECN. In many countries, these children acquire the nationality of the adoptive parents ex lege if certain conditions are fulfilled (see above $\S 2 . B$ ). In a couple of countries, option rights exist. See 21-12 (1) FRA and 19 (5) LUX (option right in case of 'weak' adoption).

84. Act 1102 of 29 December 1999.

85. Gerard-René de Groot, Stantsangehörigkeitsrecht im Wandel, 233. 


\section{K. PERSONS OF A CERTAN ETHNICITY}

In Greece persons of Greek ethnicity are facilitated by the grant of a kind of option right (5 GRE, see also 12,13 and 19 GRE). Compare the German provision described in $\S$ 2.J.

As already mentioned above, this facilitation is problematic in view of 5 (1) ECN because it could be classified as a positive discrimination based on ethnic origin.

L. VARIA

Children and grandchildren of Italians have an option right to Italian nationality if they live two years in Italy after having attained the age of majority. They can opt even earlier, if they enter into (military) service of Italy (4 (1) (a) ITA).

The child born abroad of a person who possessed Luxembourg nationality may acquire this nationality by lodging a declaration of option between the age of 18 and 25. During the year prior to the declaration of option the person involved must have had his habitual residence in Luxembourg; in total he must have lived there for at least 5 years (19 (2) LUX).

The Italian and Luxembourg option rights are an extension of the preferential treatment of former nationals.

\section{Some elements for an evaluation}

Reading the list of categories of persons entitled to an option right or entitled to naturalization in the various countries nearly all the categories listed in art. 6 (4) ECN which should be facilitated in respect of the acquisition of nationality, are mentioned. Stateless persons and refugees alone do not have as such a right of option in any of the countries studied for this publication. In respect of stateless persons born on the territory, § 2.C.2 mentions that in many countries they acquire the nationality of the country of birth ex lege, in several other countries they have option rights (see $\S 3 . \mathrm{B}$ ).

Of course, not all the categories mentioned in art. 6 (4) ECN have option rights in all countries. In some countries, facilitation of the acquisition of nationality by naturalization is preferred. At first sight, this seems to be a completely different approach. However, one should realize that a controlled option procedure is more or less the same as an efficient naturalization procedure. If naturalization is a right which can be enforced if the conditions for naturalization are fulfilled, it does not really matter whether a category of persons has a controlled option right or a privileged position in respect of the conditions for naturalization. 
If a strict option right is granted the position of the persons involved is quite different. Such a right goes in the direction of acquisition ex lege, but pays attention to the will of the person involved.

It is, by the way, not necessary for a state to make a choice between both types of option constructions. They can be used alongside each other for different categories of persons.

Many of the option rights granted to different categories of persons are limited in time: the option right has to be used within a certain period of time. This is completely understandable, for example, for the cases where children or young adults have an option right to acquire the nationality of a parent or to reacquire a nationality lost by them during their minority.

Such a limitation is less understandable in cases where the option right is granted because the person has lived his whole life, or at least for a considerable period, in the country of residence and therefore built up close ties with this country. I would like to submit that these ties become closer and closer if somebody continues to live in the country involved. A limitation of this category of option rights is therefore, in principle, not justified.

An age limitation of these option rights can only be defended if it is likely that persons would like to postpone the exercise of the option right until a moment, where one does not need to fulfil certain obligations. In the past, this could happen in almost all countries in respect of military service obligations.

It is fascinating to notice how many countries have, inter alia, grounds for ex lege acquisition based on territorial elements (birth on the territory (ius soli/ double ius soli) or residence within the territory (ius domicilii: residence of a parent or residence of the person involved) or provide for option rights based on these elements. The details of these regulations vary considerably from country to country. However, their aim is always to promote the nationality integration of persons permanently living on a state's territory. It would therefore be desirable to recommend legislators to include in their nationality legislation grounds for acquisition based on a territorial link and to allow the choice between some alternatives.

It is interesting to see that some countries grant option rights to categories of persons which are not mentioned in the list of art. 6 (4) ECN. The most interesting category is the preferential treatment of persons who were treated as a national in good faith. There is a relationship between this option right and the issue of certification and proof of nationality (see 10 and $11 \mathrm{ECN}$ ). It is desirable to study these issues and to elaborate recommendations. 


\section{$\S 4$. Some concluding Remarks}

In light of the various rules described above some suggestions can be made.

1) In respect of the grounds for acquisition ex lege:

a) Exceptions made with regard to children born abroad should be drafted in a way that never leads to situations of statelessness (see for example, Recommendation R 99 (18) of the Committee of Ministers of the Council of Europe on the avoidance and the reduction of stateless, in rule II A (a)).

b) If for one of the reasons mentioned above, a legislator wants to restrict the transmission of nationality iure sanguinis a patre in case of children born out of wedlock, the restriction should be no wider than is necessary in order to achieve the goal of the restriction.

c) Full adoption of a minor should have nationality consequences ex lege (both in the case of an adoption by a decree of the own courts as in the case of foreign adoptions recognized because of rules of private international law).

d) A special study should be made of the possibilities which parents possess to represent the interest of their children in nationality matters, of the rules regarding the extension of the acquisition, or loss of a nationality by a parent to his (minor) children, and of the possibilities which children have in order to renounce, or reacquire a nationality acquired, or lost during their minority.

e) Certain ius soli oriented ways of acquisition of nationality (ex lege or by way of option) should be encouraged in order to promote the nationality integration of persons born on the territory of a state. A double ius soli rule (or the residenceoriented variation) should be recommended in order to promote the nationality integration of families permanently living on the territory of a state.

f) In respect of the nationality provisions on foundlings, art. 6 (1) (b) ECN gives a very concrete rule. It is desirable to promote the implementation of this rule by states.

2) In respect of the grant of option rights.

a) The exercise of residence based option rights to a nationality should not be limited in time if the person involved continues to live in the country involved.

b) It is desirable to recommend that legislators include in their nationality legislation grounds for acquisition based on territorial elements and to allow the choice between some alternatives. 
c) Persons who were treated for a long period as a national and who were in good faith should either acquire the nationality involved by operation of law or should have the possibility to acquire this nationality by declaration of option.

d) The rules on certification and proof of nationality should be studied in detail in order to elaborate recommendations.

e) It is necessary to study both the categories of persons who possess a right of option and the categories of persons who are facilitated in respect of the acquisition of nationality by way of naturalization in order to draft recommendations elaborating art. $6(4)$. 


\section{Annex 1}

\section{Conclusions of the 2nd European Conference on Nationality}

The participants of the Conference, having discussed the various topics introduced by the rapporteurs, called on the Council of Europe, through its Committee of Experts on Nationality (CJ-NA), to take account of the discussions at this Conference and in particular to:

1. Develop the principles and rules of the European Convention on Nationality with regard to:

- conditions for the acquisition of nationality (in particular issues of residence, family ties, children's rights and adoption),

- the question of the right to a given nationality and

- statelessness in particular relating to State succession.

2. Pay particular attention in its future work to:

- the relationship between integration and acquisition of nationality,

- the question of when distinctions in the field of nationality law might amount to discrimination,

- the effect of other aspects of human rights issues on nationality matters.

3. Consider the regulation, at a national, bilateral and multilateral level of problems arising from:

- nationality in relation to State succession,

- multiple nationality. 


\section{Annex 2}

List of nationality statutes

Austria

Staatsbürgerschaftsgesetz 1965, Act of 15. July 1965, Bundesgesetzblatt 1965, 68 . Stück vom 11. August 1965, p. 1171, No. 250, most recently amended by Staatsbürgerschaftsnovelle 1998, Bundesgesetzblatt I, No 124/1998, in force on 1 January 1999

Belgium

Code de la nationalité belge/ Wetboek van de Belgische nationaliteit, Act of 28 June 1984, Moniteur belge 12 July 1984, p. 10.095-10.114, most recently amended by Act of 1 March 2000, Moniteur belge/ Belgisch Staatsblad 6 April 2000, in force on 1 May 2000

Czech Republic

Act on the acquisition and loss of nationality No 40/1993, most recently amended by Act No 194/1999

Denmark

Lov om dansk infodsret, Act Nr. 352 of 27 May 1950, Lov Tidende of 14 June 1950, (amended by - inter alia - Act Nr. 1102 of 29 December 1999) most recently amended by Lov Nr 193 of 5 April 2002 (adds after Par. 8 the Par. 8A, 8B and 8C regarding deprivation of Danish nationality in case of fraud committed in respect of the acquisition of Danish nationality)

\section{Estonia}

Act on citizenship of 19 January 1995, most recently amended by Act of 8 December 1998

\section{Finland}

Act Nr. 401/68 of 28 June 1968, Finlands Författningssamling 1968, Nr. 401, p. 963, , most recently amended by Act 482/1998, in force since 15 August 1998

France

Code civil, Art. 17-33-2, most recently amended by Act 99-1141 of 29 December 1999, Journal Officiel Nr. 302 of 30 December 1999

\section{Germany}

Staatsangehörigkeitsgesetz, as amended by Act of 15 July 1999, Bundesgesetzblatt I 1999 , p. $1618-1624$ 


\section{Greece}

(Act on Greek Nationality), Act. Nr 3370/1955, Ephemeris tes Kyberneseos, Nr. 258 of 23 September 1955, most recently amended by Act 2623/1998, in force on 25 June 1998; Act 2647/ 1998 and Act 2790/2000

Hungary

Act LV of 1993 on Hungarian nationality, most recently amended by Act XXXII of 2001 (in force on 1 July 2001)

Iceland

Lög um Íslenskan Ríkisborgararétt, Act Nr. 100 of 23 December 1952, most recently amended by Act $\mathrm{Nr} 82$ of 16 June 1998

\section{Ireland}

Irish Nationality and Citizenship Act, Act Nr. 26 of 17 July 1956, Acts of the Oireachtas 1956, p. 439 - inter alia - amended by the Irish Nationality and Citizenship Act 1994, most recently amended by the Irish Nationality and Citizenship Act 2001 (Act 15/2001) of 5 June 2001.

Italy

Legge sulla cittadinanza italiana, Act Nr. 91 of 5 February 1992, Gazetta Ufficiale 15 February 1992, Nr. 38

Luxembourg

Loi sur la nationalité luxembourgeoise, Act of 22 February 1968, Mém. 1968, 91; Texte coordinée 11 December 1986, Mém. 1986, 2354, most recently amended by Statute of 24 July 2001, Mémorial 2001, 101; texte coordinée 26 oktober 2001, Mémorial 2001, 129 (p. 2598-2604), in force on 1 January 2002.

\section{Moldova}

Legea Cetateniei Republicii Moldova, Act of 2 June 2000, Monitorul Oficial Nr. 98-101 709 of 10 August 2000

Netherlands

Rijkswet op het Nederlanderschap, Act of 18 December 1984, Staatsblad 1984, 627. This Act is amended by Act of 21 December 2000, Staatsblad 2000, 618 and by the Act of 18 April 2002, Staatsblad 2002, 222

Norway

Lov om Norsk Riksborgarrett, Act of 8 December 1950, Lov Tidende Nr. 49 of 19 December 1950 - inter alia - amended by Act of 11 June 1999, $\mathrm{Nr}, 38$, in force since 1 December 1999, most recently amended by Act of 15 June 2001, Nr. 71, in force on 1 October 2001 . 
Poland

Ustawa o obywatelstwie polskim, Act of 15 February 1962, Dziennik Ustaw Rzeczypospolitej Polskiej 1962, Nr. 10 of 21 February 1962, poz. 49; several times amended; a consolidated version of the Act was published in Dziennik Ustaw Rzeczypospolitej Polskiej 2000, Nr. 28, poz. 353.

\section{Portugal}

Lei da Nacionalidade portuguesa, Act 37/81 of 3 October 1981, Diário da República, 1st serie, Nr. 228, p. 2648, most recently amended by Act 25/94, Diário da República, serie 1-A of 19 August 1994. See for the implementation of these Acts Legislative Decree 322/82, Diário da República, 1st serie of 12 August 1982 and Legislative Decree 253/94, Diário da República, serie 1-A of 20 October 1994.

\section{Slovakia}

Act No 40/1993

Slovenia

Citizenship Act of 25 June 1991, Official Gazette No. 1/91-I, amended by Acts published in the Official Gazette 30/91-I, 38/92 and 13/94

\section{Spain}

Art. 17-26 Código civil, as amended by Act 18/1990 of 17 December 1990, Boletin Oficial del Estado, Nr. 3 of 18 December 1990, most recently amended by Act 29/95 of 2 November 1995

\section{Sweden}

Lag om svenskt medborgarskap, Act. No. 82 of 1 March 2001, in force on 1 July 2001. This Act replaced the old Lag om Svenskt Medborgarskap, Act Nr. 382 of 22 June 1950, Svensks Författningssamling of 30 June 1950, p. 717, amended by - inter alia Act 29/1995 of 2 November 1995, most recently amended by Act of 26 November 1998.

\section{Switzerland}

Bundesgesetz über Erwerb und Verlust des Schweizerbürgerrechts, Bundesblatt 1952 III, 137, most recently amended by Act of 24 March 2000, in force since 1 September 2000. In Switserland some bills proposing very important amendments to the nationality act are pending in parliament. See for information on these proposals Internetsite www.etrangers.ch.

\section{United Kingdom}

British Nationality Act 1981, most recently amended by the British Overseas Territories Act of 26 February 2002 